\title{
XANTHATIN FROM Xanthium spinosum
}

A. Babakhodzhaev, Sh. Z. Kasymov, and G. P. Sidyakin

We have investigated the epigeal part of Xanthium spinosum L. (spiny cocklebur), family Compositae, collected in the Tashkent region (flowering period, June, 1972).

The air-dry plant was extracted with hot water and the aqueous extract was treated with chloroform. The solvent was distilled off in vacuum. The yield of extractive substances was $0.2 \%$. The res in was separated by chromatography on a column of neutral alumina (activity grade $\mathrm{IV}$ ). The petroleum ether eluate yielded a substance with the composition $\mathrm{C}_{15} \mathrm{H}_{18} \mathrm{O}_{3}, \mathrm{mp} 114^{\circ} \mathrm{C}$ [benzene-petroleum ether $(4: 1)$ ] with $\mathrm{R}_{f} 0.58$ in the ethyl acetate-petroleum ether $(2: 3)$ system; with a $1 \%$ solution of vanillin in concentrated sulfuric acid, the spot gave a crimson color. The same spot was observed on a chromatogram of the resin even before its separation on the column.

UV spectrum: $\lambda \underset{\max }{\operatorname{ethanol}} 210,235,275,310 \mathrm{~nm}(\log \varepsilon 4.09,3.57,4.39,3.49)$. IR spectrum: $1770 \mathrm{~cm}^{-1}$ (carbonyl of a $\gamma$-lactone) and $1690 \mathrm{~cm}^{-1}$ ( $\alpha$-unsaturated ketone).

On the basis of its spectral characteristics and a mixed melting point with an authentic sample, the substance isolated was identified as the sesquiterpene lactone xanthat in [1].

This is the first time that xanthatin has been isolated from Xanthium spinosum.

LITERATURE CITED

1. P. G. Deuel and T. A. Geissman, J. Amer. Chem. Soc., 포, 3778 (1957).

Institute of the Chemistry of Plant Substances, Academy of Sciences of the Uzbek SSR. Translated from Khimiya Prirodnykh Soedinenii, No. 4, p. 559, July-August, 1973. Original article submitted March 27, 1973.

(C) 1975 Plenum Publishing Corporation, 227 West 17th Street, New York, N.Y. 10011. No part of this publication may be reproduced, stored in a retrieval system, or transmitted, in any form or by any means, electronic, mechanical, photocopying, microfilming, recording or otherwise, without written permission of the publisher. A copy of this article is available from the publisher for $\$ 15.00$. 